\title{
Model Pertumbuhan Populasi Satu Spesies Dengan Tundaan Waktu Diskrit
}

\author{
Onoy Rohaeni \\ Program Studi Matematika, FMIPA, Universitas Islam Bandung \\ onoyrohaeni@unisba.ac.id
}

\begin{abstract}
Abstrak. Model pertumbuhan populasi adalah model Matematika yang menggambarkan pertumbuhan populasi. Salah satu model pertumbuhan populasi adalah model pertumbuhan logistik. Dengan menggunakan asumsi kaidah logistik bahwa pada masa tertentu jumlah populasi akan mendekati titik kesetimbangan (equilibrium). Untuk menganalisis masing-masing titik kesetimbangan, dilakukan proses linearisasi. Proses linearisasi dilakukan dipersekitaran titik kesetimbangan dengan menggunakan prosedur perturbasi. Pada proses perturbasi ini, parameter perturbasi yang digunakan sangat kecil, yaitu antara nol dan 1, sehingga akan mengakibatkan sangat dekat dengan titik kesetimbangan. Pada titik kesetimbangan ini jumlah kelahiran dan kematian dianggap sama, sehingga grafiknya akan mendekati konstan (zero growth).
\end{abstract}

Kata kunci: model pertumbuhan populasi, titik kesetimbangan, waktu diskrit.

Abstract. (One Species Population Growth Model with Discrete Time Delays) The population growth model is a Mathematical model that describes population growth. One population growth model is a logistical growth model. By using the assumption of logistical rules that at certain times the population will approach equilibrium. To analyze each equilibrium point, a linearization process is carried out. The linearization process is carried out around the equilibrium point using the perturbation procedure. In this perturbation process, the perturbation parameter used is very small, which is between zero and 1, so that it will result very close to the equilibrium point. At this equilibrium point the number of births and deaths is considered the same, so the graph will be close to constant (zero growth).

Keywords: population growth model, equilibrium point, discrete time.

\section{Pendahuluan}

Model pertumbuhan populasi adalah model Matematika yang menggambarkan pertumbuhan populasi. Menurut Yulianti (2005), ada beberapa model pertumbuhan populasi diantaranya adalah:

a) Model diskrit. Model yang menggambarkan pola pertumbuhan populasi dengan memandang interval waktu pengamatan sebagai variabel yang diskrit.

b) Model eksponensial. Model yang menggambarkan pola pertumbuhan populasi dengan memandang interval waktu pengamatan sebagai variabel yang kontinu.

c) Model pertumbuhan populasi dengan distribusi umur. Model ini membagi populasi dalam kelompok umur dengan memandang setiap kelompok umur mempunyai kontribusi khusus terhadap model populasi.

d) Model logistik. Model pertumbuhan populasi yang mempertimbangkan keterbatasan lingkungan, sehingga laju pertumbuhan populasi tergantung pada kerapatan populasinya.

Seiring dengan pembahasan tersebut, dalam tulisan ini akan dibahas mengenai pertumbuhan populasi model logistik dengan tundaan waktu diskrit. Waktu tunda ini menyebabkan penurunan populasi, tetapi untuk selanjutnya terjadi peningkatan, sehingga terjadi osilasi pada pertumbuhan populasi.

Untuk menggambarkan pertumbuhan suatu populasi, pada tahun 1830 Verhulst memperkenalkan suatu model pertumbuhan logistik. Pada model pertumbuhan logistik ini dihasilkan solusi yang berbentuk fungsi yang monoton naik atau monoton turun, dimana fungsi ini memberikan penafsiran 
bahwa jumlah populasi akan terus bertambah atau akan terus berkurang. Tetapi dalam kenyataannya, sepanjang waktu pertumbuhan keadaan lingkungan dapat berubah. Keadaan lingkungan yang berubah akan mengakibatkan pertumbuhan mengalami penundaan.

\section{Model Pertumbuhan Populasi}

Populasi adalah bentuk kumpulan organisme yang paling sederhana pada suatu komunitas, karena hanya terdiri dari satu spesies saja (Yulianti, 2005). Misalnya, diasumsikan bahwa dalam suatu ekosistem terdapat satu spesies dengan persediaan makanan cukup. Jika $N(t)$ menyatakan banyaknya populasi pada saat $t$, dengan $t \geq 0$, maka Haberman (1997) mendefinisikan bahwa laju pertumbuhan populasi pada interval waktu $(\Delta t)$ sebagai

$$
R(t)=\frac{N(t+\Delta t)-N(t)}{\Delta t N(t)}
$$

Jika besar populasi didekati dengan suatu fungsi kontinu terhadap waktu $t$ yang diasumsikan diferensiabel, maka laju pertumbuhan sesaat dinyatakan dengan,

$$
R(t)=\lim _{\Delta t \rightarrow 0} R(t)=\lim _{\Delta t \rightarrow 0} \frac{N(t+\Delta t)-N(t)}{\Delta t N(t)}=\frac{1}{N} \frac{d N}{d t}
$$

Berdasarkan persamaan ini, maka yang dimaksud laju pertumbuhan populasi adalah laju pertumbuhan sesaat $(R(t))$ dikalikan dengan banyaknya populasi $(N(t))$, sehingga

$$
\frac{d N(t)}{d t}=R(t) N(t)
$$

Dalam model ini laju pertumbuhan $(R(t))$ dianggap bergantung kepada populasi saat itu, sehingga $R(t)$ merupakan fungsi dari $N(t)$. Jadi, persamaan (1) dapat dinyatakan sebagai

$$
\frac{d N(t)}{d t}=R(N(t))
$$

Hubungan antara $R(t)$ dan $N(t)$ menurut Verhust (1830), Pearl dan Reed (1920) adalah bahwa laju pertumbuhan dipengaruhi oleh angka pertumbuhan tanpa pengaruh lingkungan, yang notasinya dilambangkan dengan bilangan positif $a$, dan efek naiknya angka kepadatan populasi, dilambangkan dengan bilangan positif $b$. Sehingga persamaan (1) menjadi

$$
\frac{d N(t)}{d t}=N(t)(a-b N(t))
$$

\section{Model Tundaan Waktu Diskrit}

Perubahan populasi di dalam suatu ekosistem tidak selalu mendekati maupun menjauhi kapasitas batas. Hal ini disebabkan individu tidak dapat melahirkan terus menerus sepanjang hidupnya. Ada beberapa individu yang belum mampu berkembang biak karena memang belum dewasa, ada juga individu yang tidak mampu berkembang biak karena mandul. Gejala ini merupakan suatu fenomena di mana suatu individu memerlukan tundaan waktu (time delay) untuk berkembang biak. Menurut Widodo (2007), pada saat populasi melebihi kapasitas batas, angka kematian cenderung lebih besar dari pada angka kelahiran, sehingga terjadilah penurunan populasi. Demikian drastisnya penurunan ini, maka menyebabkan populasi turun sampai di bawah kapasitas batas.

Berdasarkan persamaan (2), yaitu 


$$
\frac{d N(t)}{d t}=N(t)(a-b N(t))
$$

laju pertumbuhan populasi bergantung kepada populasi saat itu, tetapi pada kenyataannya (Purnomo, 2000) mengungkapkan bahwa sepanjang waktu pertumbuhan keadaan lingkungan dapat berubah. Beberapa proses biologi yang melibatkan stadium pertumbuhan, keadaan lingkungan yang berubah, akan mengakibatkan pertumbuhan akan mengalami penundaan. Waktu tunda ini menyebabkan penurunan populasi, tetapi kemudian terjadi peningkatan. Dengan demikian, maka akan terjadi osilasi pada pertumbuhan populasi.. Model laju pertumbuhan populasi seperti ini, disimbolkan oleh $N\left(t-t_{d}\right)$, dengan $t_{d}$ adalah waktu tundaan (time delay). Kebergantungan ini mungkin berujud dari beberapa jumlah individu dewasa, jumlah individu yang mandul, kondisi lingkungan pada saat itu, dan lain-lain. Fenomena ini (Habermen, 1977) dimodelkan dalam persamaan

$$
\frac{1}{N(t)} \frac{d N(t)}{d t}=R\left(N\left(t-t_{d}\right)\right)
$$

Persamaan ini dinamakan sebagai persamaan diferensial tundaan (differential equation of delay).

Berdasarkan persamaan (2), persamaan logistik model pertumbuhan populasi dengan tundaan waktu $\left(t_{d}\right)$ dinyatakan sebagai

$$
\frac{d N(t)}{d t}=N(t)\left(a-b N\left(t-t_{d}\right)\right)
$$

Secara analitik model pertumbuhan logistik dengan tundaan waktu sangat sulit untuk diselesaikan. Oleh karena itu, untuk memperoleh solusi numerik dari model pertumbuhan logistik dengan tundaan waktu ini, penyelesaiannya akan digunakan formulasi waktu disktrit.

Secara umum model pertumbuhan populasi satu spesies tanpa tundaan waktu diskrit oleh Habermen (1997) didefinisikan sebagai

$$
\frac{N(t+\Delta t)-N(t)}{\Delta t N(t)}=R(N(t))
$$

atau

$$
N(t+\Delta t)-N(t)=R \Delta t N(t)
$$

dengan $\Delta t$ adalah interval waktu. Selanjutnya, model pertumbuhan populasi logistik tanpa tundaan waktu diskrit dengan $R$ konstan dinyatakan sebagai:

$$
N(t+\Delta t)-N(t)=R_{0} \Delta t N(t)
$$

di mana laju pertumbuhan proposional dengan banyaknya populasi.Sebagai contoh bahan makanan yang dibatasi, maka laju pertumbuhan akan menurun. Situasi seperti ini (Habermen, 1977), memodelkan pertumbuhan logistik diskrit dengan tundaan waktu sebagai

$$
N(t+\Delta t)-N(t)=\Delta t N(t)\left[a-b N\left(t-t_{d}\right)\right]
$$

dengan pengukuran dilakukan pada setiap interval waktu $\Delta t$. Jadi, berdasarkan persamaan (5) ini, apabila $t_{d}=\Delta t$, akan diperoleh

$$
N(t+\Delta t)-N(t)=\Delta t N(t)[a-b N(t-\Delta t)]
$$

atau

$$
N(t+\Delta t)=N(t)[1+a \Delta t-b \Delta t N(t-\Delta t)]
$$

Untuk menganalisa persamaan (6) ini, diasumsikan suatu populasi $N(t)$ bertambah secara teratur setiap tahun $(\Delta t=1)$. Jadi, penambahan individu pada area yang diberikan bergantung pada berapa banyak 
sumber makanan yang dikonsumsi oleh individu tersebut selama tahun sebelumnya. Untuk menyelesaikan persamaan (6), diperlukan syarat awal

$$
t=m \Delta t \text { dan } N(t)=N(m \Delta t) \equiv N_{m} \text { dengan } m=1,2,3, \ldots
$$

Sehingga,

$$
\begin{aligned}
& N_{1}=N(\Delta t)=N(t) \\
& N_{2}=N(2 \Delta t)=N_{1}[1+a \Delta t-b \Delta t N(\Delta t-\Delta t)] \\
& N_{3}=N(3 \Delta t)=N_{2}[1+a \Delta t-b \Delta t N(2 \Delta t-\Delta t)] \\
& \vdots \\
& N_{m}=N(m \Delta t)=N_{m+1}[1+a \Delta t-b \Delta t N(m \Delta t-\Delta t)]
\end{aligned}
$$

Dengan demikian, solusi dari persamaan (6) dapat dilakukan dengan menggunakan perhitungan numerik sebagai berikut:

$$
N(t+\Delta t)-N(t)=\Delta t N(t)[a-b N(t-\Delta t)]
$$

Oleh karena, $t=m \Delta t$ dan $N(t)=N(m \Delta t) \equiv N_{m}$ dengan $m=1,2,3,4, \ldots$. , maka persamaan (7) menjadi:

$$
N_{m+1}-N_{m}=N_{m}\left(a \Delta t-b \Delta t N_{m-1}\right)
$$

di mana: $N_{m+1}=$ jumlah populasi pada $m+1$ unit ; $N_{m}=$ jumlah populasi pada $m$ unit; dan $N_{m-1}=$ jumlah populasi pada $m-1$ unit .

Penyederhanaan dari persamaan (7) ditulis sebagai

$$
N_{m+1}-N_{m}=N_{m}\left(\alpha-\beta N_{m-1}\right)
$$

dengan $\alpha=a \Delta t$ dan $\beta=b \Delta t$.

Untuk menyelesaikan persamaan (9) ini akan dilakukan dengan menggunakan proses linearisasi. Linearisasi dilakukan dengan menggunakan metode perturbasi (perturbation method).

\section{Linearisasi Model Tundaan dengan Menggunakan Metode Perturbasi}

Metode perturbasi dikerjakan dengan cara menganalisis regangan (displacement) terhadap populasi keseimbangan. Misalkan

$$
N(t)=\frac{\alpha}{\beta}+\varepsilon N_{1}(t)
$$

atau setara dengan

$$
N_{m}=\frac{\alpha}{\beta}+\varepsilon y_{m}
$$

dengan regangan terhadap kapasitas batas adalah $\varepsilon N_{1}(t)=\varepsilon y_{m}$.

Diasumsikan $\left|\varepsilon y_{m}\right|<<\frac{\alpha}{\beta}$ ( $<<$ adalah jauh lebih kecil dari). Dengan mensubstitusikan persamaan

(11) ke dalam persamaan (8) menghasilkan

$$
\frac{\alpha}{\beta}+\varepsilon y_{m+1}-\left(\frac{\alpha}{\beta}+\varepsilon y_{m}\right)=\left(\frac{\alpha}{\beta}+\varepsilon y_{m}\right)\left(\alpha-\beta\left(\frac{\alpha}{\beta}+\varepsilon y_{m-1}\right)\right)
$$




$$
\begin{aligned}
\frac{\alpha}{\beta}+\varepsilon y_{m+1}-\frac{\alpha}{\beta}-\varepsilon y_{m} & =\left(\frac{\alpha}{\beta}+\varepsilon y_{m}\right)\left(\alpha-\alpha-\beta \varepsilon y_{m-1}\right) \\
\varepsilon y_{m+1}-\varepsilon y_{m} & =\left(\frac{\alpha}{\beta}+\varepsilon y_{m}\right)\left(-\beta \varepsilon y_{m-1}\right) \\
\varepsilon\left(y_{m+1}-y_{m}\right) & =\left(-\beta \varepsilon y_{m-1}\right)\left(\frac{\alpha}{\beta}+\varepsilon y_{m}\right) \\
y_{m+1}-y_{m} & =-\beta y_{m-1}\left(\frac{\alpha}{\beta}+\varepsilon y_{m}\right)
\end{aligned}
$$

Karena $\left|\varepsilon y_{m}\right|<<\frac{\alpha}{\beta}$, maka bentuk tak linear $-\beta y_{m-1}\left(\varepsilon y_{m}\right)$ dapat diabaikan. Sehingga diperoleh persamaan linearisasi

$$
y_{m+1}-y_{m}=-\alpha y_{m-1}
$$

Persamaan (13) ini merupakan persamaan differensi linear orde dua koefisien konstan. Untuk menyelesaikan persamaan (13), diasumsikan bahwa $y_{m}=r^{m}$. Selanjutnya, nilai $r$ ditentukan dengan mensubstitusikan $y_{m}=r^{m}$ ke dalam persamaan (13), sehingga menghasilkan

$$
r^{m+1}-r^{m}+\alpha r^{m-1}=0
$$

Jika tiap suku pada persamaan (14) dibagi dengan $r^{m-1}$, maka akan diperoleh persamaan kuadrat untuk $r$ yang dinyatakan dengan

$$
r^{2}-r+\alpha=0
$$

dimana akar-akar dari persamaan kuadrat di atas adalah

$$
r_{1,2}=\frac{1 \pm \sqrt{1-4 \alpha}}{2}
$$

Jadi, solusi umum dari persamaan (13) dapat ditulis sebagai

$$
y_{m}=c_{1} r_{1}^{m}+c_{2} r_{2}^{m}
$$

Dari akar-akar $r_{1}$ dan $r_{2}$, akan diperoleh sebagai berikut:

1. Untuk $0<\alpha<\frac{1}{4}$

Jika $0<\alpha<\frac{1}{4}$, maka akar-akar dari persamaan (15) adalah $0<r_{1}<1$ dan $0<r_{2}<1$. Apabila diurutkan akan menghasilkan $0<r_{1}<r_{2}<1$.

Oleh karena itu dari persamaan (16) diperoleh

$$
\lim _{m \rightarrow \infty} y_{m}=0
$$

Persamaan ini menunjukan bahwa populasi mendekati kapasitas batas, untuk $t \rightarrow \infty$.

Karena berlaku untuk setiap syarat awal, maka kapasitas batas stabil. 
2. Untuk $\alpha>\frac{1}{4}$

Jika $\alpha>\frac{1}{4}$, maka akar-akar dari persamaan (15) adalah bilangan kompleks sekawan, yaitu:

$$
r_{1}=\frac{1+i \sqrt{4 \alpha-1}}{2} \quad \text { dan } \quad r_{2}=\frac{1-i \sqrt{4 \alpha-1}}{2}
$$

3. Untuk $\frac{1}{4}<\alpha<1$. Solusi berosilasi di sekitar titik kesetimbangan dan menuju ke nol. Hal ini berarti kesetimbangannya stabil.

Pada kasus $\alpha=1$, solusi berosilasi tetap atau tidak menjauh maupun mendekati titik kesetimbangan. Sedangkan untuk $\alpha>1$, populasi melebihi tingkat kesetimbangan dan cenderung menjauhi titik kesetimbangan. Pertumbuhan populasi yang berosilasi dengan jumlah yang semakin besar dan tidak menuju ke titik kesetimbangan disebut dengan osilasi divergen. Hal ini menyebabkan kesetimbangan menjadi tidak stabil.

\section{Kesimpulan}

Berdasarkan pembahasan mengenai model pertumbuhan logistik dengan waktu tunda, dapat disimpulkan bahwa penundaan dalam pertumbuhan populasi yang mengikuti model pertumbuhan logistik menyebabkan terjadinya osilasi sehingga mempengaruhi kestabilan di sekitar titik kesetimbangan. Secara umum semakin besar waktu tunda dalam pertumbuhan populasi, menyebabkan ketidakstabilan terhadap pertumbuhan. Dalam hal ini terjadi ledakan populasi dan juga populasi dapat berkurang, sehingga akhirnya mengalami kepunahan.

\section{Referensi}

[1] Forys, U., Czochra, M.A. Logistik Equations in Tumour Growth Modelling, Int. J. Appl. Math. Comput. Sci., Vol. 13, No. 3, 317-325. 2003

[2] Haberman, Richard. Mathematical Models: Mechanical Vibrations, Population Dynamics and Traffic Flow. Prentice-Hall Inc. New Jersey. 1977

[3] Timuneno, Henny M. Model Pertumbuhan Logistik dengan Tundan Waktu. Jurnal Matematika, Vol. 11 No. 1, April 2008: 43-51. 2008.

[4] Vries, G. \& Hillen T. A Short Course in Mathematical Biologi. Tuebingen. 2004.

[5] A.B. Yulianti, Icih Sukarsih. Model Distribusi Kelimpahan Populasi Pada Komunitas Plankton di Kolam Percobaan. Jurnal Matematika UNISBA. Vol. 7 No. 1, 2008.

[6] E. Harahap, F. H. Badruzzaman, M. Y. Fajar. Metoda Iteratif Pada Permasalahan Menara Hanoi. Jurnal Matematika UNISBA. Vol. 6 No. 1, 2007. 
